\title{
Recombinant Hendra viruses expressing a reporter gene retain pathogenicity in ferrets
}

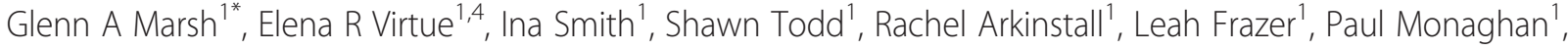 \\ Greg A Smith ${ }^{1}$, Christopher C Broder ${ }^{2}$, Deborah Middleton ${ }^{1}$ and Lin-Fa Wang ${ }^{1,3}$
}

\begin{abstract}
Background: Hendra virus (HeV) is an Australian bat-borne zoonotic paramyxovirus that repeatedly spills-over to horses causing fatal disease. Human cases have all been associated with close contact with infected horses.

Methods: A full-length antigenome clone of HeV was assembled, a reporter gene (GFP or luciferase) inserted between the $P$ and $M$ genes and transfected to 293T cells to generate infectious reporter gene-encoding recombinant viruses. These viruses were then assessed in vitro for expression of the reporter genes. The GFP expressing recombinant HeV was used to challenge ferrets to assess the virulence and tissue distribution by monitoring GFP expression in infected cells.
\end{abstract}

Results: Three recombinant HeV constructs were successfully cloned and rescued; a wild-type virus, a GFPexpressing virus and a firefly luciferase-expressing virus. In vitro characterisation demonstrated expression of the reporter genes, with levels proportional to the initial inoculum levels. Challenge of ferrets with the GFP virus demonstrated maintenance of the fatal phenotype with disease progressing to death consistent with that observed previously with the parental wild-type isolate of HeV. GFP expression could be observed in infected tissues collected from animals at euthanasia.

Conclusions: Here, we report on the first successful rescue of recombinant $\mathrm{HeV}$, including wild-type virus and viruses expressing two different reporter genes encoded as an additional gene cassette inserted between the P and $M$ genes. We further demonstrate that the GFP virus retained the ability to cause fatal disease in a wellcharacterized ferret model of henipavirus infection despite the genome being an extra 1290 nucleotides in length.

Keywords: Henipavirus, Hendra virus, Reverse genetics, Rescue system, Pathogenesis, Paramyxovirus, Ferret, Zoonotic disease

\section{Background}

Hendra virus $(\mathrm{HeV})$ is a zoonotic paramyxovirus harboured by Australian mainland flying foxes from which it is believed to be transmitted directly to horses. $\mathrm{HeV}$ first emerged in 1994 in Hendra, a suburb of Brisbane, Australia, leading to an outbreak of acute respiratory disease in 21 thoroughbred horses, of which 14 died [1-3]. During this outbreak, two horse trainers also became infected with the virus, one fatally. In horses, $\mathrm{HeV}$ causes a severe, often fatal, febrile illness associated with respiratory and neurological signs [4]. Since its emergence in

\footnotetext{
* Correspondence: glenn.marsh@csiro.au

${ }^{1}$ CSIRO Animal, Food and Health Sciences, Australian Animal Health Laboratory, Geelong, VIC 3220, Australia

Full list of author information is available at the end of the article
}

Queensland, Australia in 1994, $\mathrm{HeV}$ spillover from flying foxes to horses has regularly recurred: with an increase in disease events occurring over the past two years [5]. Thirty-nine disease events have occurred resulting in the death or euthanasia of seventy-six horses and one dog, with a case fatality of $75 \%$ in the horses.

$\mathrm{HeV}$ is the prototype species of the genus Henipavirus, within the subfamily Paramyxovirinae [6,7]. Nipah virus $(\mathrm{NiV})$ is the only other virus officially classified within the Henipavirus genus. NiV was first identified during a major outbreak of acute respiratory disease in pigs in peninsular Malaysia in 1998-99. Over one million pigs were culled in Malaysia to prevent the continued spread of the virus. Over 265 farm and abattoir workers exposed to infected pigs were infected by NiV, resulting in 
a total of 105 deaths in Malaysia and Singapore [8-10]. Since the outbreak of disease in Malaysia and Singapore, $\mathrm{NiV}$ re-emerged in Bangladesh in 2001, with continued re-emergence and human cases almost annually since in Bangladesh and sporadically in India [11,12]. Differences in transmission have also been observed between the Bangladesh and Malaysian strains of NiV. NiV Bangladesh has been shown to cause direct bat-to-human transmission without the involvement of an intermediary or amplifying host. Human-to-human spread of $\mathrm{NiV}$ in Bangladesh has also been documented [12-15]. Because of the broad host range and the high mortality rates associated with these viruses, both $\mathrm{HeV}$ and $\mathrm{NiV}$ have been classified as a biosafety level 4 (BSL-4) agents.

Recently, we described a novel paramyxovirus, Cedar virus (CedPV), which displayed many of the distinguishing characteristics of the henipaviruses, including similar genome length and organisation, it displayed antigenic crossreactivity with henipaviruses and used the same host cell molecule (ephrin B2) as a receptor for entry during infection [16]. Interestingly in preliminary animal challenge studies, CedPV did not cause disease in ferrets and guinea pigs, both of which are susceptible to fatal disease by the henipaviruses. In addition, a near full length genome sequence has been described for a bat-borne virus from Ghana, Africa [17], that shows around 50\% sequence identity with the henipaviruses, including CedPV. Henipa-like viruses have also been detected serologically in bats in Thailand [18], China [19], Madagascar [20] and West Africa [21], with successful virus isolation obtained from Lyle's flying foxes in Cambodia [22].

Reverse genetics of negative strand RNA viruses allow for the creation of recombinant infectious and replication-competent viruses with specific mutations or insertions. Often, researchers have inserted the green fluorescent protein (GFP) gene into such viruses allowing for the real-time monitoring of virus replication and spread, either within cell culture or in vivo within an infected host. The expression of GFP allows for the detection of virus infection in tissues without the need for antibody-specific detection methods. The generation of recombinant henipaviruses will be an extremely powerful tool to monitor viral infections both in realtime for imaging and in a high-throughput approach for screening activities. They will also play a pivotal role in our understanding of pathogenesis of henipaviruses at the molecular level through the generation, rescue and testing of specific mutation variants. Rescue systems have previously been reported for $\mathrm{NiV}$ [23-25], here we report the generation of recombinant $\mathrm{HeV}$ in which the GFP (HeV-GFP) or firefly luciferase gene (HeV-Luc) has been inserted as an additional transcriptional unit between the $\mathrm{P}$ and $\mathrm{M}$ genes, and we assess their biological characteristics both in vitro and in vivo.

\section{Results and discussion}

\section{Rescue of recombinant viruses}

A full length antigenome clone of $\mathrm{HeV}$ (Hendra virus/ horse/1994/Hendra) was prepared and used for modification by the insertion of GFP and firefly luciferase reporter genes. Reporter genes were inserted between the $\mathrm{P}$ and $\mathrm{M}$ genes, including the untranslated regions from the 3' end of the $\mathrm{P}$ gene and the 5' end of the $\mathrm{M}$ gene (Figure 1). The rule of six was maintained in both the GFP and luciferase constructs (HeV-GFP: 19,524 nucleotides; HeV-Luc: 20,460 nucleotides). The HeV-GFP construct is similar to a NiV-GFP infectious clone previously reported [25], however in the NiV-GFP virus, GFP was inserted between the $\mathrm{N}$ and $\mathrm{P}$ genes. In this study, the reporter genes were inserted between $\mathrm{P}$ and $\mathrm{M}$ in order to keep the ratio of $\mathrm{N}$ and $\mathrm{P}$ consistent with wild-type virus. This was considered important for optimal replication and for maintenance of full virulence. The full HeV-Luc construct at 20,460 nucleotides resulted in the largest reported genome of a paramyxovirus.

Rescue of recombinant $\mathrm{HeV}$ for wild-type, HeV-GFP and $\mathrm{HeV}$-Luc viruses were achieved by co-transfection of human $293 \mathrm{~T}$ cell in $12.5 \mathrm{~cm}^{2}$ flasks with the full length antigenome plasmid, N, P and L protein expression vector and pCAGGS T7 RNA polymerase. Two days after transfection, Vero cells $\left(5 \times 10^{5}\right.$ cells $)$ were added to the $293 \mathrm{~T}$ cell monolayers. In successful experiments, CPE was obvious within 3 days following the addition of the Vero cells, with CPE reaching maximal levels around 7 days post transfection. Supernatants were collected from the transfected cell monolayers and clarified by centrifugation and used to infect Vero cell monolayers to prepare virus stocks for further study.

\section{In vitro characterisation}

Growth characteristics of the 3 recombinant viruses were compared in Vero cells (Figure 2). Replication of each virus followed a similar pattern, at 24 hours, the recombinant viruses show slightly lower titres compared to the parental virus however, and all reached a maximal titre of $3-5 \times 10^{7} \mathrm{TCID}_{50} / \mathrm{mL}$ by 48 hours post infection.

In order to determine expression of the GFP reporter genes within infectious virus, cells were infected with $\mathrm{HeV}-\mathrm{GFP}$ an MOI of 0.01 and imaged by fluorescent

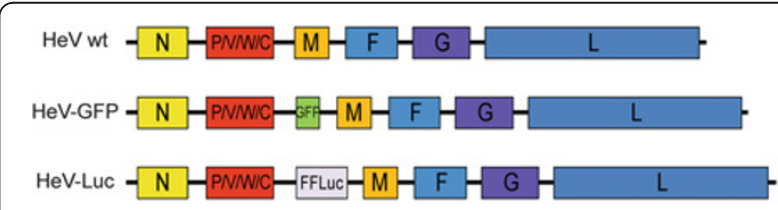

Figure 1 Schematic representation of the genomes of each of the recombinant viruses. Full gene cassettes including the $5^{\prime} U T R$ from the M gene, the reporter gene and the $3^{\prime}$ UTR of the P gene were inserted for expression of the GFP or luciferase. 

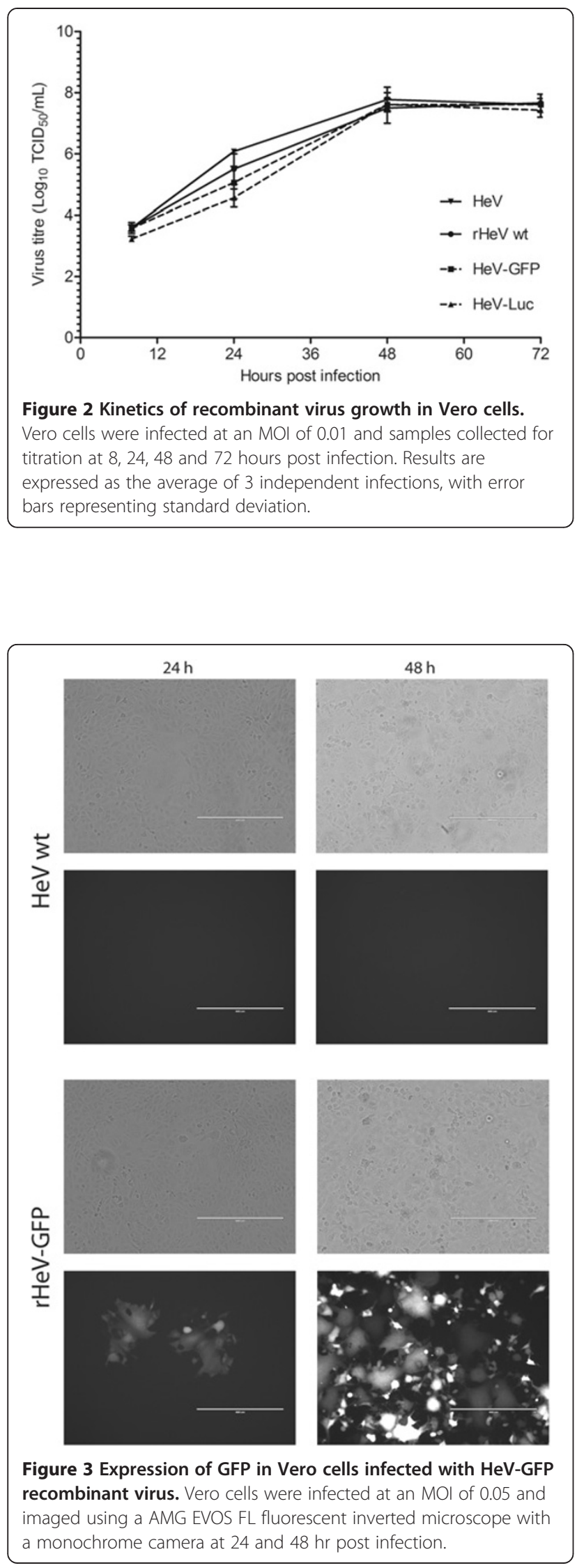

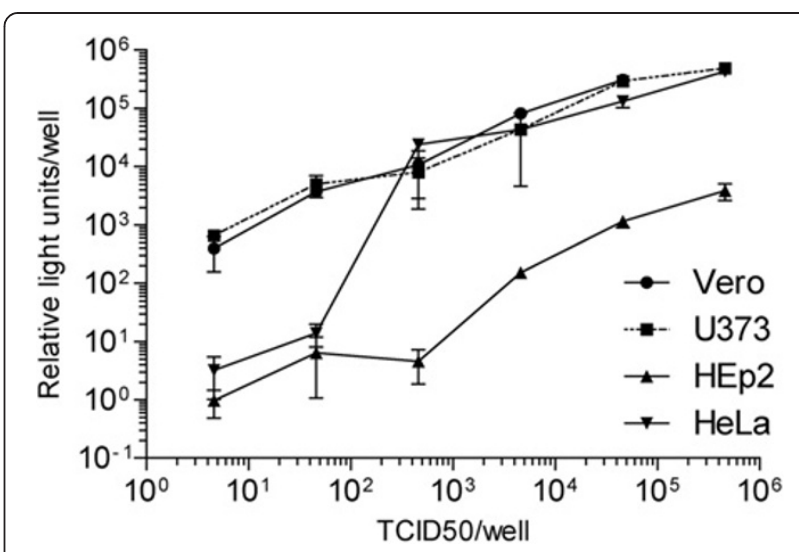

Figure 4 Expression of luciferase by the recombinant HeV-Luc. Vero, HeLa, HEp2 and U373 human cells were infected with various amounts of HeV-Luc. At 24 hours post infection, luciferase activity in cells was measured by lysing cells using BrightGlo reagent

(Promega) and reading on a Synergy $\mathrm{H} 4$ microplate reader (Biotek Instruments Inc). Results represent the average of 4 independent infections with error bars representing standard deviation. All values have been normalised to uninfected cells (relative light units of 1).

microscopy at 24 and 48 hours post infection. GFP positive cells were visible at 24 hours post infection and by 48 hours all cells were fluorescent, consistent with the spread of virus and infection of all cells by 48 hours (Figure 3). Stable GFP expression by HeV-GFP was assessed by serially passing the virus 5 times to fresh cell. Strong GFP expression was maintained through the 5 passes. The GFP expression allows for real-time monitoring of virus replication and spread in infected cells.

Expression of luciferase by the recombinant $\mathrm{HeV}$-Luc was assessed by infecting cells with various amounts of virus for 24 hours. Luciferase activity in cells was then measured by lysing the cells using BrightGlo reagent (Promega) and reading on a Synergy H4 microplate reader (Biotek Instruments Inc). As virus dose increased, the level of luciferase increased proportionately (Figure 4). Differences were observed when different cell lines were used in this study, demonstrating the usefulness of this virus to quantitatively assess the infection and/or replication efficiency of $\mathrm{HeV}$ in different cell lines. Luciferase expression can be used for high-throughput monitoring of virus replication, hence they are a useful tool for screening drug candidates. This virus is currently being used for a genome-wide RNAi screen of human genes critical for $\mathrm{HeV}$ replication.

\section{In vivo characterisation}

To determine whether the insertion of a reporter gene into $\mathrm{HeV}$ attenuated the virus in vivo, ferrets were exposed to $5,000 \mathrm{TCID}_{50}$ of $\mathrm{HeV}$-GFP virus by the oronasal route. This dose was previously determined to be lethal for ferrets using the parental wild-type isolate 


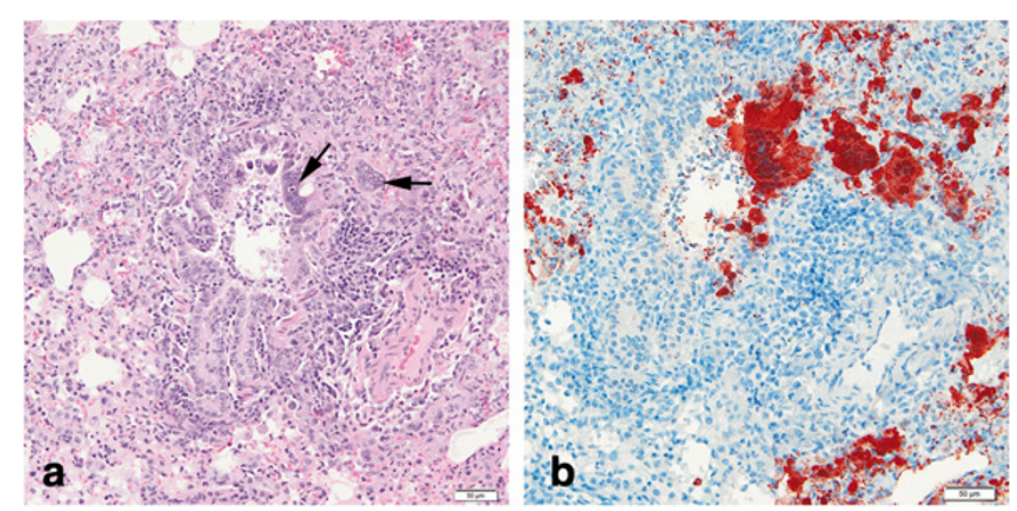

Figure 5 Necrotising bronchoalveolitis with epithelial syncytia in lung of ferret infected with HeV-GFP virus. (a) $H$ and $E$ and (b) immunohistochemical staining of HeV N protein showing presence of antigen in red. Arrow indicates syncytia.

of $\mathrm{HeV}$ : two ferrets became febrile on day 6 post challenge and were euthanased on reaching pre-determined humane endpoints on day 6 or day 7 post challenge [26]. Lesions in these animals included systemic vasculitis, bronchoalveolitis, glomerular necrosis, and lymphoid necrosis, associated with syncytial cell formation and $\mathrm{HeV}$ antigen deposition in lesional tissues. Disease progression with the HeV-GFP virus was consistent with that observed using wild-type virus, with ferrets becoming febrile from 3 to 6 days post challenge and reaching predetermined humane endpoints on day 7 or 8 post challenge ( 2 ferrets on each day). Gross post mortem and microscopic pathology findings were also similar to the previous report of $\mathrm{HeV}$ infection in ferrets. These include hemorrhagic lymph nodes and petechial hemorrhages throughout the lungs and renal cortices, with necrotising rhinitis, systemic vasculitis, syncytial cell formation, necrotising bronchoalveolitis (Figure 5), lymphadenitis, and splenic and renal glomerular necrosis accompanied by $\mathrm{HeV}$ antigen deposition in affected tissues. Real-time PCR analysis of HeV RNA in clinical samples and in tissues collected at euthanasia matched

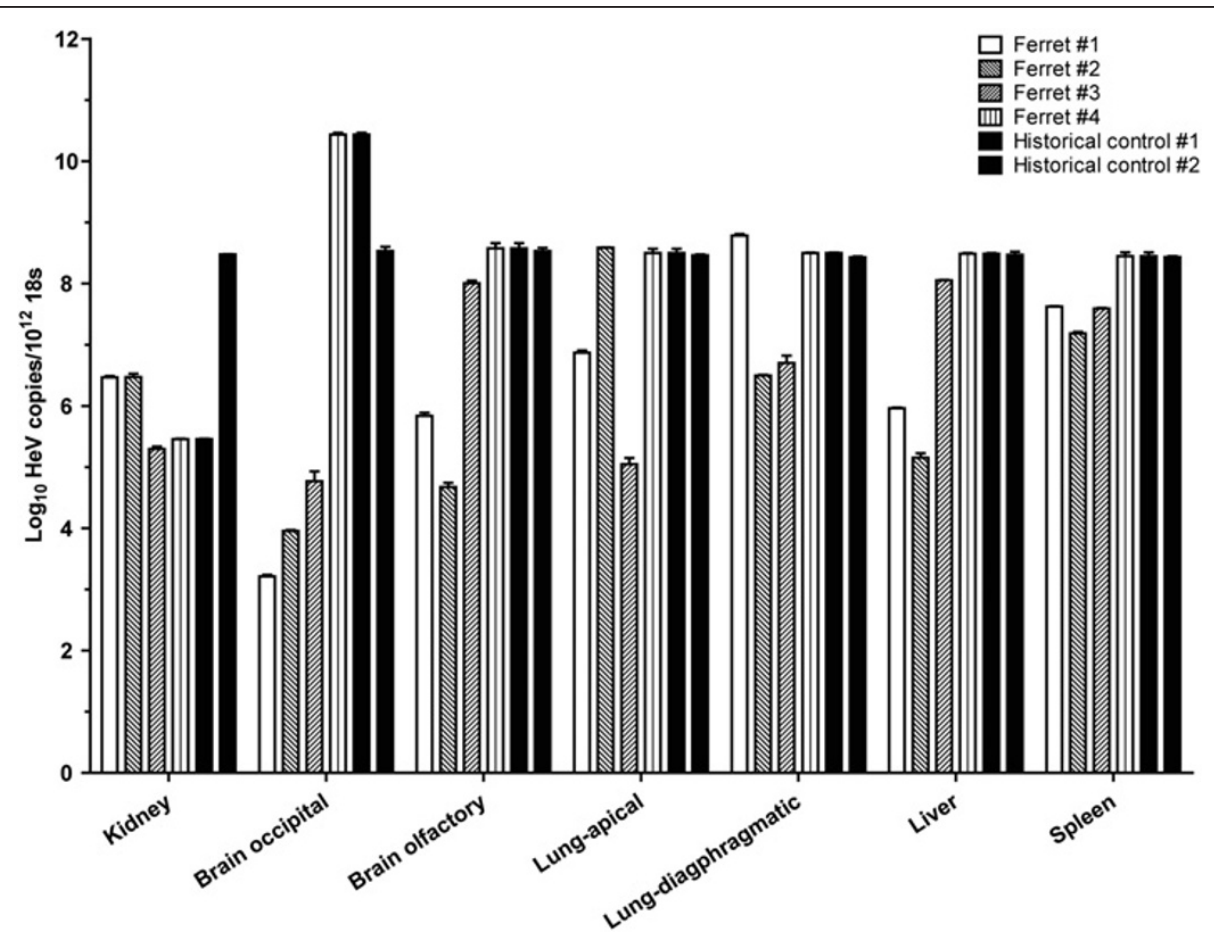

Figure 6 Relative abundance of HeV-GFP RNA in different tissues of the ferret. Various tissues were collected at post mortem examination and analysed for HeV-GFP viral load by real-time PCR. Values are expressed relative to ribosomal 185 copies. 

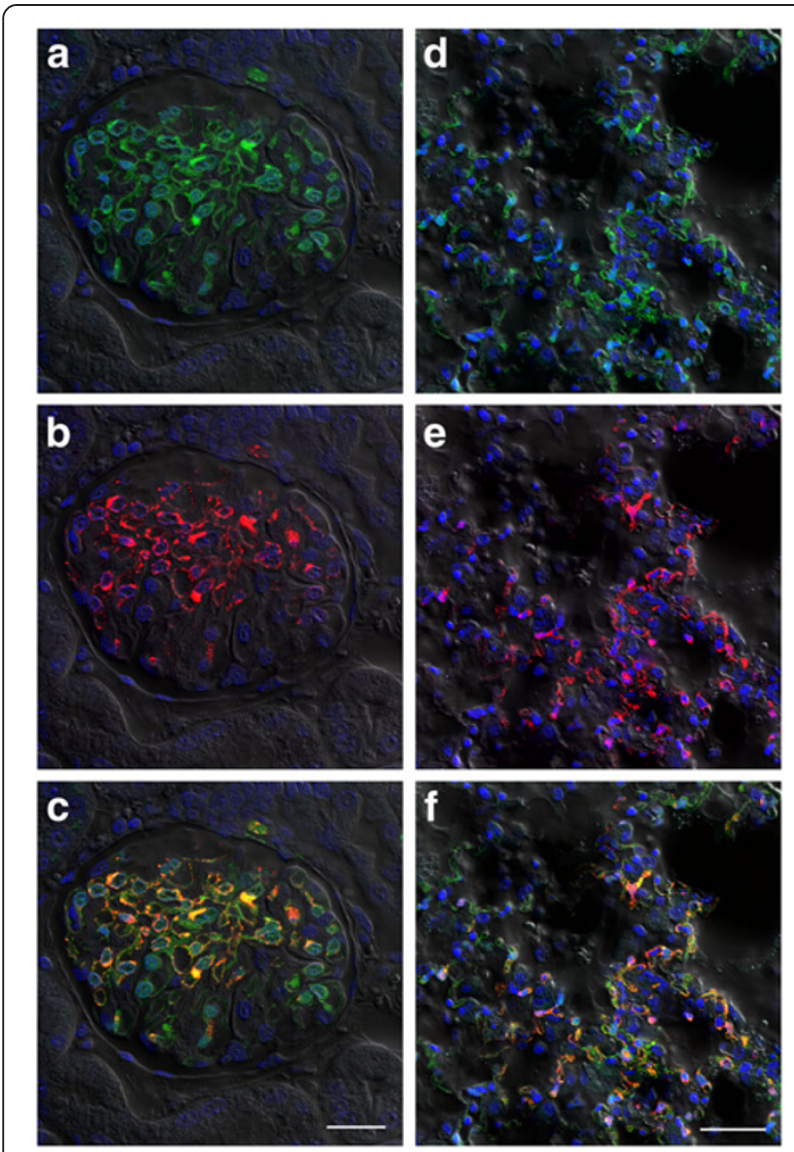

Figure 7 Expression of GFP in tissues sectioned from HeV-GFP challenged ferrets. Ferrets were challenged with 5,000 TCID ${ }_{50}$ of HeV-GFP and succumbed to disease on days 7 and 8. At necropsy, kidney $(\mathbf{a}, \mathbf{b}, \mathbf{c})$ and lung $(\mathbf{d}, \mathbf{e}, \mathbf{f})$ samples were collected, fixed with paraformaldehye, sectioned and imaged by confocal microscopy. To assess sensitive of GFP expression (green; $a$ and $d$ ) to traditional staining techniques, HeV nucleocapsid protein (red; $b$ and e) was costained using rabbit anti- HeV N sera detected with anti-rabbit conjugated Alexafluor 568. Composite images (c and f) show both GFP and HeV N labelling. Scale bars: $\mathrm{c}=25 \mu \mathrm{m}, \mathrm{f}=40 \mu \mathrm{m}$.

that observed previously (Figure 6) [26].

Imaging of tissue sections from lung, kidney and spleen of HeV-GFP infected ferrets by confocal microscopy showed significant numbers of GFP-containing cells. To determine whether all infected cells were GFPpositive, sections were co-stained for $\mathrm{HeV}$ nucleocapsid (Figure 7). This showed that imaging of GFP expression in tissues for $\mathrm{HeV}$ infection was as sensitive as immunofluorescent labelling of tissue sections.

\section{Conclusions}

Here we report the first successful rescue of replicationcompetent recombinant $\mathrm{HeV}$, including both wild-type $\mathrm{HeV}$ as well as recombinant viruses encoding either the GFP or luciferase genes by genetic insertion between the $\mathrm{P}$ and $\mathrm{M}$ genes. The rescue of the HeV-Luc virus resulted in a paramyxovirus with the largest functional reported genome to date. Challenge of ferrets with $\mathrm{HeV}$ GFP demonstrated that the insertion of GFP into the virus genome did not moderate its virulence, with GFP expression being observed in tissues collected from ferrets at euthanasia. The HeV-Luc virus is currently being utilized as a powerful tool for studying host genes important for the replication of $\mathrm{HeV}$ (unpublished data).

\section{Methods}

\section{Cells and virus}

293T cells (ATCC CRL-11268) were maintained in Dulbecco's Modified Eagle's Medium (DMEM) high glucose (Invitrogen), supplemented with 10\% fetal bovine serum (FBS), $100 \mathrm{U} / \mathrm{mL}$ penicillin, $100 \mathrm{mg} / \mathrm{mL}$ streptomycin, $4 \mathrm{mM}$ L-glutamine. African green monkey (Vero - ATCC CCL-81) cells were maintained in EMEM supplemented with $10 \% \mathrm{FBS}, 100 \mathrm{U} / \mathrm{mL}$ penicillin, and $100 \mathrm{mg} / \mathrm{mL}$ streptomycin. HeV (Hendra virus/horse/ 1994/Hendra isolate, GenBank Accession AF017149) was isolated in Vero cells from the lung of a horse infected in the Brisbane outbreak in 1994 and was passaged and triple plaque purified in Vero cells. All work with live $\mathrm{HeV}$ was carried out within the BSL4 facilities at the Australian Animal Health Laboratory, Geelong Australia.

\section{Generation of plasmids and rescue of recombinant HeVs}

Vero cells were infected with $\mathrm{HeV}$ and when maximal CPE was observed cell supernatants were collected and virus concentrated by ultracentrifugation $(280,000 \mathrm{~g}$ for 45 minutes). Pellet was then resuspended in buffer RLT (Qiagen) and removed from the BSL4 laboratory. RNA was extracted using a Qiagen RNEasy kit and reverse transcribed to cDNA. Using a panel of PCR primers, large $(3-5 \mathrm{~kb})$ fragments were generated by PCR and cloned into pOLTV5 [27] between a T7 RNA promoter and a hepatitis delta virus ribozyme. Full open reading frames for $\mathrm{HeV} \mathrm{N}, \mathrm{P}$ and $\mathrm{L}$ genes, the essential components needed for viral RNA transcription and replication, were cloned into pTM-I, a T7 driven mammalian expression plasmid. In addition, the T7 RNA polymerase gene was PCR amplified from BSR/T7 cells and cloned into pCAGGS. All plasmid inserts were sequenced to obtain at least 2 -fold sequence coverage to ensure no mutations relative to the reference sequences.

To generate recombinant viruses, $1 \times 10^{6} 293 \mathrm{~T}$ cells were transfected with pTM-I HeV N $(1.25 \mu \mathrm{g})$, pTM-I HeV P $(0.8 \mu \mathrm{g})$, pTM-I HeV L $(0.4 \mu \mathrm{g})$, full-length $\mathrm{HeV}$ genome plasmid $(3.5 \mu \mathrm{g})$ and pCAGGS T7 $(2 \mu \mathrm{g})$ using $7 \mu \mathrm{L}$ Lipofectamine 2000 (Invitrogen). Media was changed on cells at 6 hours post transfection and then $5 \times 10^{5}$ Vero cells were added to transfected 293T cells after 2 days. Cells were observed for 7 days for the 
generation of syncytia, at which time, supernatant was passaged to fresh Vero cells $\left(75 \mathrm{~cm}^{2}\right.$ flasks) to amplify recombinant virus. When maximal CPE was obtained, supernatants were clarified by low speed centrifugation $(1000 \mathrm{~g})$, aliquoted, stored at $-80^{\circ} \mathrm{C}$ and the $50 \%$ tissue culture infective dose $\left(\mathrm{TCID}_{50}\right) / \mathrm{mL}$ calculated using the Reed and Muench method [28].

\section{Animal studies}

Procedures involving live animals were approved by the Commonwealth Scientific and Industrial Research Organisation, Australian Animal Health Laboratory and Animal Ethics Committee. Four male ferrets, aged 12-18 months, were exposed oronasally to 5000 TCID $_{50}$ of HeV-GFP. This challenge dose was selected as the wild-type isolate has been shown to be lethal in ferrets at this dose (unpublished observations). Ferrets were monitored daily for indications of disease including fever and alertness. Euthanasia was performed at predetermined humane endpoints as previously described [29]. Shedding samples, blood and urine were collected on days 3 and 6 post-exposure as well as immediately prior to euthanasia and various tissues collected at post mortem examination.

\section{Imaging of tissues}

Samples of brain, lung, spleen and kidney tissues from $\mathrm{HeV}-\mathrm{GFP}$ infected ferrets were dissected into approximately $1 \mathrm{~cm}$ cubes and fixed for $48 \mathrm{hr}$ in $4 \%$ paraformaldehyde in phosphate buffered saline (PBS). They were stored at $4^{\circ} \mathrm{C}$ in PBS. Sections were cut at $70 \mu \mathrm{m}$ on a Leica VT1000 vibrating microtome (Leica Microsystems). Sections were blocked in PBS containing $0.5 \%$ bovine serum albumin (PBS/BSA) overnight and then incubated in rabbit anti-HeV $\mathrm{N}$ protein diluted 1:1000 in PBS/BSA. Following $3 \times 10 \mathrm{~min}$ washes in PBS, the bound antibody was detected with goat anti-rabbit IgG conjugated to Alexa 568 (Life Technologies) diluted 1:200 in PBS/BSA, followed by $3 \times 10 \mathrm{~min}$ washes in PBS. Nuclei were labelled by incubation of sections in a 1:1000 dilution of DAPI (Sigma, Sydney) for $30 \mathrm{~min}$ and following $2 \times \mathrm{H}_{2} \mathrm{O}$ washes, the sections were mounted in Vectashield (Vector laboratories). Coverslips were sealed with nail varnish and the sections imaged with a Leica SP5 confocal microscope.

\section{Competing interests}

The authors declare that they have no competing interests.

\section{Authors' contributions}

GAM conceived the study, carried out the molecular work, in vitro

characterisation, processed animal tissues, analysed samples and drafted the manuscript. ERV participated in the molecular work. IS provided clones and participated in the molecular work. ST participated in the molecular work. RA carried out the animal infection trials. LF assisted with the animal work. PM performed the confocal imaging work. GAS provided clones and participated in the molecular work. CCB conceived the study, provided funds and edited the manuscript. DM designed the animal study, provided veterinary pathological assistance and drafted the manuscript. LFW conceived the study and drafted the manuscript. All authors read and approved the final manuscript.

\section{Acknowledgements}

We thank Leanne Dickson and Dianne Green for providing technical assistance and Jackie Pallister and Gary Crameri for critical review of the manuscript. This work was supported in part by a CSIRO Office of the Chief Executive Postdoctoral fellowship (GAM), a CEO Science Leader Award (LFW) from the CSIRO Office of the Chief Executive and NIH grant Al054715 (CCB). The authors acknowledge the support of the Australian Microscopy and Microanalysis Facility (AMMRF) for the AAHL Biosecurity Microscopy Laboratory.

\section{Author details}

${ }^{1}$ CSIRO Animal, Food and Health Sciences, Australian Animal Health Laboratory, Geelong, VIC 3220, Australia. ${ }^{2}$ Department of Microbiology and Immunology, Uniformed Services University, Bethesda, MD 20814, USA. ${ }^{3}$ Program in Emerging Infectious Diseases, Duke-NUS Graduate Medical School, Singapore 169857, Singapore. ${ }^{4}$ Current address - Monash Institute of Medical Research, Clayton, VIC 3168, Australia.

Received: 3 December 2012 Accepted: 21 March 2013

Published: 25 March 2013

\section{References}

1. Murray K, Rogers R, Selvey L, Selleck P, Hyatt A, Gould A, Gleeson L, Hooper $P$, Westbury $H$ : A novel morbillivirus pneumonia of horses and its transmission to humans. Emerg Infect Dis 1995, 1:31-33.

2. Selvey LA, Wells RM, McCormack JG, Ansford AJ, Murray K, Rogers RJ, Lavercombe PS, Selleck P, Sheridan JW: Infection of humans and horses by a newly described morbillivirus. Med J Aust 1995, 162:642-645.

3. Murray K, Selleck P, Hooper P, Hyatt A, Gould A, Gleeson L, Westbury H, Hiley $L$, Selvey $L$, Rodwell $B$, et al: A morbillivirus that caused fatal disease in horses and humans. Science 1995, 268:94-97.

4. Marsh GA, Haining J, Hancock TJ, Robinson R, Foord AJ, Barr JA, Riddell S, Heine $H G$, White JR, Crameri G, et al: Experimental infection of horses with Hendra virus/Australia/horse/2008/Redlands. Emerg Infect Dis 2011, 17:2232-2238.

5. Clayton BA, Wang LF, Marsh GA: Henipaviruses: an updated review focusing on the pteropid reservoir and features of transmission. Zoonoses Public Health 2012, 60:69-83.

6. Wang LF, Yu M, Hansson E, Pritchard LI, Shiell B, Michalski WP, Eaton BT: The exceptionally large genome of Hendra virus: support for creation of a new genus within the family Paramyxoviridae. J Virol 2000, 74:9972-9979.

7. Eaton BT, Mackenzie JS, Wang LF: Henipaviruses. In Fields Virology, 5th edition. Edited by Knipe DM, Howley PM. Philadelphia: Lippincott, Williams and Wilkins; 2007:1587-1600.

8. Paton NI, Leo YS, Zaki SR, Auchus AP, Lee KE, Ling AE, Chew SK, Ang B, Rollin PE, Umapathi T, et al: Outbreak of Nipah-virus infection among abattoir workers in Singapore. Lancet 1999, 354:1253-1256.

9. Chua KB, Bellini WJ, Rota PA, Harcourt BH, Tamin A, Lam Sai Kit K, Ksiazek TG, Rollin PE, Zaki SR, Shieh WJ, et al: Nipah virus: a recently emergent deadly paramyxovirus. Science 2000, 288:1432-1435.

10. Chua KB, Goh KJ, Wong KT, Kamarulzaman A, Tan PSK, Ksiazek TG, Zaki SR, Paul G, Lam SK, Tan CT: Fatal encephalitis due to Nipah Virus among pig-farmers in Malaysia. Lancet 1999, 354:1257-1259.

11. Hsu VP, Hossain MJ, Parashar UD, Ali MM, Ksiazek TG, Kuzmin I, Niezgoda M, Rupprecht C, Bresee J, Breiman RF: Nipah virus encephalitis Reemergence, Bangladesh. Emerg Infect Dis 2004, 10:2082-2087.

12. Luby SP, Hossain MJ, Gurley ES, Ahmed BN, Banu S, Khan SU, Homaira N, Rota PA, Rollin PE, Comer JA, et al: Recurrent zoonotic transmission of Nipah virus into humans, Bangladesh, 2001-2007. Emerg Infect Dis 2009, 15:1229-1235.

13. ICDDR, B: Nipah Encephalitis outbreak over wide area of Western Bangladesh, 2004. Health and Science Bulletin 2004, 2:7-11.

14. Homaira N, Rahman M, Hossain MJ, Epstein JH, Sultana R, Khan MS, Podder G, Nahar K, Ahmed B, Gurley ES, et al: Nipah virus outbreak with person-to -person transmission in a district of Bangladesh, 2007. Epidemiol Infect 2010, 138:1630-1636. 
15. Gurley ES, Montgomery JM, Hossain MJ, Bell M, Azad AK, Islam MR, Molla MA, Carroll DS, Ksiazek TG, Rota PA, et al: Person-to-person transmission of Nipah virus in a Bangladeshi community. Emerg Infect Dis 2007, 13:1031-1037.

16. Marsh GA, de Jong C, Barr JA, Tachedjian M, Smith C, Middleton D, Yu M, Todd S, Foord AJ, Haring V, et al: Cedar virus: a novel henipavirus isolated from Australian bats. PLOS Pathog 2012, 8:e1002836.

17. Drexler JF, Corman VM, Muller MA, Maganga GD, Vallo P, Binger T, Gloza-Rausch F, Rasche A, Yordanov S, Seebens A, et al: Bats host major mammalian paramyxoviruses. Nat Commun 2012, 3:796.

18. Wacharapluesadee S, Lumlertdacha B, Boongird K, Wanghongasa S, Chanhome L, Rollin P, Stockton P, Rupprecht C, Ksiazek T, Hemachudha T: Bat Nipah virus, Thailand. Emerg Infect Dis 2005, 11:1949-1951.

19. Li Y, Wang J, Hickey AC, Zhang Y, Wu Y, Zhang H, Yuan J, Han Z, McEachern $J$, Broder CC, et al: Antibodies to Nipah or Nipah-like viruses in bats, China. Emerg Infect Dis 2008, 14:1974-1976.

20. Lehle C, Razafitrimo G, Razainirina J, Andriaholinirina N, Goodman SM, Faure C, Georges-Courbot MC, Rousset D, Reynes JM: Henipavirus and Tioman virus antibodies in pteropodid bats, Madagascar. Emerg Infect Dis 2007, 13:159-161.

21. Hayman D, Suu-Ire R, Breed A, McEachern J, Wang L, Wood J, Cunningham A: Evidence of henipavirus infection in West African fruit bats. PLoS One 2008, 3:e2739.

22. Reynes JM, Counor D, Ong S, Faure C, Seng V, Molia S, Walston J, GeorgesCourbot MC, Deubel V, Sarthou JL: Nipah virus in Lyle's flying foxes, Cambodia. Emerg Infect Dis 2005, 11:1042-1047.

23. Ciancanelli MJ, Volchkova VA, Shaw ML, Volchkov VE, Basler CF: Nipah virus sequesters inactive STAT1 in the nucleus via a P gene-encoded mechanism. J Virol 2009, 83:7828-7841.

24. Lo MK, Peeples ME, Bellini WJ, Nichol ST, Rota PA, Spiropoulou CF: Distinct and overlapping roles of Nipah virus $\mathrm{P}$ gene products in modulating the human endothelial cell antiviral response. PLoS One 2012, 7:e47790.

25. Yoneda M, Guillaume V, Ikeda F, Sakuma Y, Sato H, Wild TF, Kai C: Establishment of a Nipah virus rescue system. Proc Natl Acad Sci U S A 2006, 103:16508-16513.

26. Pallister J, Middleton D, Wang LF, Klein R, Haining J, Robinson R, Yamada M, White J, Payne J, Feng YR, et al: A recombinant Hendra virus $G$ glycoprotein-based subunit vaccine protects ferrets from lethal Hendra virus challenge. Vaccine 2011, 29:5623-5630

27. Peeters BP, de Leeuw OS, Koch G, Gielkens AL: Rescue of Newcastle disease virus from cloned CDNA: evidence that cleavability of the fusion protein is a major determinant for virulence. J Virol 1999, 73:5001-5009.

28. Reed $\mathrm{L}$, Muench $\mathrm{H}$ : A simple method of estimating fifty percent endpoints. Am J Hyg 1938, 27:493-497.

29. Bossart KN, Zhu Z, Middleton D, Klippel J, Crameri G, Bingham J, McEachern JA, Green D, Hancock TJ, Chan YP, et al: A neutralizing human monoclonal antibody protects against lethal disease in a new ferret model of acute Nipah virus infection. PLoS Pathog 2009, 5:e1000642.

doi:10.1186/1743-422X-10-95

Cite this article as: Marsh et al:: Recombinant Hendra viruses expressing a reporter gene retain pathogenicity in ferrets. Virology Journal 2013 10:95.

\section{Submit your next manuscript to BioMed Central and take full advantage of:}

- Convenient online submission

- Thorough peer review

- No space constraints or color figure charges

- Immediate publication on acceptance

- Inclusion in PubMed, CAS, Scopus and Google Scholar

- Research which is freely available for redistribution 